\title{
Komiks w czasach niekoniecznie normalnych
}

Jerzy Szyłak 


\section{Komiks w czasach niekoniecznie normalnych}

Jerzy Szyłak

TEKSTY DRUGIE 2017, NR 5, S. 147-167

DOI: $10.18318 /$ td.2017.5.9

$\mathbf{W}$ okresie międzywojennym w Polsce ukazywało się wiele różnych komiksów, ale do tych publikacji nie przywiązywano zbyt wiele uwagi. Były wśród nich przedruki komiksów zachodnich, historyjki obrazkowe robione na ich wzór i podobieństwo oraz takie, które robiono po to, by były inne od sprowadzonych z Zachodu. Czasem było jeszcze dziwniej, ponieważ sprowadzane z zagranicy komiksy „polonizowano", nadając bohaterom rodzime imiona i powierzając tworzenie opowieści o nich polskim twórcom. Ów przedwojenny świat opowieści obrazkowych został praktycznie zapomniany i odkryty na nowo przez Adama Ruska, który opisał go w książce Tarzan, Matołek i inni. Cykliczne historyjki obrazkowe w Polsce w latach 1919-1939 (2001). Obecnie autor ów zabiega o to, by najlepsze z dzieł z tamtego okresu przypomnieć, i udało mu się doprowadzić do uruchomienia serii „Dawny komiks polski" wydawanej przez Wydawnictwo Komiksowe. Swoją żmudną pracę dokumentalisty, który ustala daty pierwodruków i autorstwo prac oraz skrupulatnie wyszukuje zapomniane publikacje, kontynuował Rusek
Jerzy Szyłak - prof. dr hab., Katedra Wiedzy o Filmie i Kulturze Audiowizualnej, Uniwersytet Gdański. Ostatnio publikował: Coś więcej, czegoś mniej. Poszukiwania formuły powieści graficznej w komiksie 1832-2015 (2016). Kontakt: listopad196o@ wp.pl 
w książce Od rozrywki do ideowego zaangażowania. Komiksowa rzeczywistość w Polsce w latach 1939-1955 (2011) i ponownie pokazal, że wielu rzeczy nie pamiętamy, o innych zaś mamy mylne pojęcie ${ }^{1}$. Mam nadzieję, że badacz ten będzie kontynuował swoją pracę, ponieważ kiedy patrzę na wypowiedzi dotyczące tego, co wydarzyło się na polskiej scenie komiksowej w ciągu ostatnich pięćdziesięciu lat, odnoszę wrażenie, że naprawdę wiele rzeczy zapomniano, a równie wiele jest źle pamiętanych.

W okresie powojennym tworzono w Polsce sporo historyjek obrazkowych, starano się ich jednak nie nazywać komiksami, gdyż tę nazwę kojarzono z amerykańską (imperialistyczną) kulturą. Przy ich realizacji trzymano się też wypracowanej przed wojną formy, opartej na oddzieleniu tekstu od obrazów. Znaczące zmiany przyszły wraz z odwilżą w 1956 roku. W 1957 roku Andrzej Piwowarczyk (jako scenarzysta) i Szymon Kobyliński (rysownik) opublikowali broszurkę komiksową zatytułowaną Stary zegar. Historyjka nosiła nadtytuł Kapitan Gleb opowiada i była opatrzona numerem jeden, co zapowiadało serię wydawniczą, numer dwa jednak się nie ukazał. Od 1957 roku w „Świecie Młodych" publikował swoje komiksy Henryk Jerzy Chmielewski. W 1958 roku w gdańskim „Wieczorze Wybrzeża” zaczęły się ukazywać komiksy Janusza Christy. W roku 1959 w bydgoskiej popołudniówce „Dziennik Wieczorny” zadebiutował Jerzy Wróblewski.

Komiks zadomowił się w „Świecie Młodych”, gdzie Chmielewski zamieszczał komiks o przygodach dwóch chłopców i uczłowieczonej małpy, zatytułowany Tytus, Romek i A'Tomek. Zadomowił się też w Bydgoszczy i Gdańsku. Wróblewski w „Dzienniku Wieczornym” publikował różne opowieści, utrzymane w przedwojennym stylu (z tekstem umieszczonym pod spodem), rozciągnięte na kilkadziesiąt odcinków każda, lecz później nie kontynuowane. Christa natomiast, na polecenie redakcji, która chciała mieć opowieść o przedstawicielu klasy pracującej, wykonującego zawód związany z morzem, wymyślił postać Kajtka Majtka, któremu później dodał kolegę imieniem Koko. We dwóch tworzyli oni parę często spotykaną w utworach komediowych: jeden był mały i sprytny, drugi - duży i niezbyt mądry, ale za to łakomy. Rysownik (który sam sobie tworzył scenariusze) także przedstawiał opowieści liczące od osiemdziesięciu do trzystu odcinków, ale we wszystkich bohaterami czynił tę samą parę marynarzy. Na początku były to historie kryminalne (Christa niewiele

1 Zob. A. Rusek Tarzan, Matołek i inni. Cykliczne historyjki obrazkowe w Polsce w latach 1919-1939, Biblioteka Narodowa, Warszawa 2001; A. Rusek Od rozrywki do ideowego zaangażowania. Komiksowa rzeczywistość w Polsce w latach 1939-1955, Biblioteka Narodowa, Warszawa 2011. 
wiedział o specyfice pracy na morzu i wcale nie miał zamiaru jej pokazywać), potem Kajtek i Koko trafili do krainy baśni, a w końcu polecieli w kosmos (ta opowieść składała się z ponad tysiąca dwustu odcinków).

Popularność gazetowych komiksów przez dłuższy czas nie przekładała się jednak na ich książkowe wydania. Pierwszy album z serii Tytus, Romek iA'Tomek ukazał się dopiero w 1966 roku i zawierał opowieść różniącą się od tego, co publikował „Świat Młodych” - bardziej nasyconą dydaktyzmem i narysowaną przez Chmielewskiego na nowo. Od tego momentu jednak kolejne tomy opowieści ukazują się regularnie co rok, aż do początku lat 8o.. Niektóre mają po kilka wydań. Trudno powiedzieć, czy zawdzięczamy to sukcesowi Tytusa, Romka i A'Tomka, czy też innym względom, ale w 1968 roku pojawił się pierwszy zeszyt nowej serii komiksowej. Nie miała ona swojej nazwy, ale ochrzczono ją od nazwiska głównego bohatera: Kapitan Żbik. W 1969 roku wystartowała kolejna seria - „Podziemny front” - oparta na serialu telewizyjnym pod tym samym tytułem. W 1970 pojawiły się komiksowe adaptacje seriali Stawka większa niż życie (opublikowano 20 odcinków) i Czterej pancerni i pies (całość została zamknięta w trzech księgach wydanych w formacie zbliżonym do Przygód Koziotka Matołka).

Mateusz Szlachtycz w swojej - napisanej z pozycji fana i kolekcjonera, wspominającego fascynacje, jakie żywił w dzieciństwie - książce Kapitan Żbik. Portret pamięciowy postawił tezę, że seria Kapitan Żbik zawdzięcza swoje istnienie (a także pewne elementy zarówno konstrukcji bohatera, jak i struktury fabularnej) sukcesowi seriali Czterej pancerni i pies oraz Stawka większa niżżycie. Z jego argumentami można się zgodzić lub nie, warto jednak niewątpliwie zwrócić uwagę na inne zjawisko, które Szlachtycz przy okazji opisał:

W roku 1966 opublikowano pierwszą księgę komiksowych przygód Tytusa, Romka i A'Tomka (scenariusz i rysunki Tadeusz [sic!] Chmielewski, Horyzonty), wtedy też powstała „Telewizja Dziewcząt i Chłopców”, gdzie pod redakcją tercetu: Maciej Zimiński, Janusz Przymanowski i Szymon Kobyliński pojawił się program Klub pancernych. Agitowano tam młodzież do łączenia się w podwórkowe załogi, co spotkało się z gorącym odzewem. Dziesiątki tysięcy dzieci z całej Polski włączyły się do zabawy w pancerniaków. ${ }^{2}$

2 M. Szlachtycz Kapitan Żbik. Portret pamięciowy, The Facto, Warszawa 2017, s. 41. 
Szlachtycz pisze o tym, że w 1966 roku w Polsce odkryto siłę oddziaływania telewizji (i szerzej kultury masowej) na młodzież. Cytuje nawet wypowiedź Przymanowskiego, świadczącą o tym, że nikt podobnego sukcesu się nie spodziewał: „Przypuszczaliśmy, że będzie się z nami bawiło tysiąc lub dwa tysiące dzieci. Tymczasem, gdy po pierwszym odcinku zawiązaliśmy «Klub Pancernych» i obiecaliśmy dostarczyć legitymacje wszystkim, którzy do nas napiszą, musieliśmy w ciągu dwóch tygodni wysłać sto tysięcy”3. Kilka stron dalej Szlachtycz dodaje bardzo trafną uwagę: „Nawet najbardziej twardogłowi partyjniacy, tacy jak komendant główny MO Tadeusz Pietrzak, musieli dostrzegać siłę propagandowego rażenia popkultury"4. W tekście Wojciecha Birka poświęconym twórczości Grzegorza Rosińskiego, który był jednym z rysowników komiksów o Żbiku, możemy z kolei przeczytać, że „Jeśli zaryzykować stwierdzenie, że do młodego grafika uśmiechnęło się wówczas szczęście, to uśmiech ten zawdzięcza on inicjatywie ówczesnego komendanta Milicji Obywatelskiej, generała Tadeusza Pietrzaka, który uznał, że «trzeba poprawić wizerunek milicji w oczach młodego pokolenia». Ponieważ najlepszą formą dotarcia do ówczesnej młodzieży wydawał się komiks, którego sprzedawane na bazarach zachodnie wydania cieszyły się ogromną popularnością, uznano, że najlepiej będzie posłużyć się właśnie tą formą przekazu"5.

Scenariusze do komiksów o Żbiku były pisane przez różne osoby (w publikacjach nazwiska autorów nie były podawane, ale Szlachtycz wymienia ich wszystkich). W dodatku część była - o czym wspomina Jerzy Jastrzębski przeróbkami utworów literackich, ukazujących się w serii Ewa wzywa $07^{6}$. Jako twórca serii wskazywany jest nieodmiennie podpułkownik MO, obecnie emerytowany Władysław Krupka, który pisał scenariusze do serii nie tylko w PRL-u, ale także na początku XXI wieku, kiedy wydawnictwo Mandragora spróbowało zdyskontować popularność dawnej serii, wydając komiks, którego bohaterem był wnuk dzielnego milicjanta. Zakończyło się to zresztą spektakularnie, aczkolwiek nie tak, jak wydawca sobie wyobrażał. Opracowanie graficzne serii powierzono rysownikowi młodego pokolenia Michałowi Śledzińskiemu (ur. 1978), który już po stworzeniu (i opublikowaniu) pierwszego

3 Tamże.

4 Tamże, s. 46.

5 W. Birek Grzegorz Rosiński i „kolorowe zeszyty”. Studium stylistyczne, w: tegoż Z teorii i praktyki komiksu. Propozycje i obserwacje, Fundacja Tranzyt/Centrala, Poznań 2014, S. 213.

6 Zob. J. Jastrzębski Komiks istereotypy, w: tegoż Czas relaksu. O literaturze masowej i jej okolicach, Ossolineum, Wrocław-Warszawa-Kraków 1982, s. 218. 
odcinka serii, dał wyraz swojej irytacji niską jakością scenariusza, umieszczając na własnym blogu wiadomość: „Pier..., nie robię”.

Przed laty Stanisław Barańczak napisał, że polska kultura popularna przypomina tańczenie kankana z portretem Lenina w tle, ale dla wielu miłośników komiksów (zarówno czytelników, jak i twórców) ów portret w tle był niewielką ceną w zamian za możliwość obcowania z historiami obrazkowymi. Dzięki serii Kapitan Żbik zaistnieli jako rysownicy komiksowi tacy twórcy jak Grzegorz Rosiński i Bogumił Polch, a Jerzy Wróblewski mógł się pojawić na rynku ogólnopolskim. Dwaj pierwsi w drugiej połowie lat 70. nawiązali współpracę z wydawnictwami zachodnimi (Rosiński ostatecznie wyjechał z kraju i osiedlił się w Belgii), a Wróblewski pozostał niemal wyłącznym rysownikiem serii od połowy 1973 roku aż do jej zamknięcia w 1982 roku i opublikował dwadzieścia cztery części opowieści o Żbiku.

Na początku lat 7o.zainteresowanie komiksem wynikało nie tylko z odkrycia jego potencjału propagandowego. Oprócz Tytusa, Romka i A'Tomka, Podziemnego Frontu i Kapitana Klossa zaczęły się wówczas pojawiać na łamach prasy (głównie w „Szpilkach”, także w „Przekroju”) komiksy satyryczne, specyficznie antyestetyczne, rysowane pokracznie i krzywo i pokazujące świat groteskowo wykrzywiony. W latach tych redaktorem „Szpilek” był Krzysztof Teodor Toeplitz, który zajmował się badaniem kultury masowej i sporo o niej pisał, zwracając uwagę także na komiks. To on odkrył amerykański komiks undergroundowy, który u schyłku lat 6o.bujnie się rozwinął, z uznaniem opisywał go w swoich publikacjach, umieszczał przedruki w prowadzonym przez siebie piśmie. Nic dziwnego, że wspierał twórców robiących rzeczy utrzymane w podobnej poetyce: Andrzeja Czeczota, Andrzeja Mleczkę, Andrzeja Krauzego, Andrzeja Dudzińskiego i innych twórców, niekoniecznie mających na imię Andrzej.

Popularność owych satyryków była ogromna. Szczególnym powodzeniem cieszyła się zwłaszcza twórczość Andrzeja Mleczki, dowcipnego, w swoich żartach bezpardonowego i przy tym śmiało poczynającego sobie z formą komiksu. Sławomir Magala poświęcił jego twórczości esej zatytułowany Komiks w kulturze narodowej. Pisał w nim o peryferyjnych formach sztuki masowej i sposobach ich kanonizacji. Prace Mleczki były w tym ujęciu przykładami utworów, które stanowią metatekstowe komentarze na temat gatunku artystycznego, z którego wyrosły ${ }^{7}$. Magala zarazem namaszczał Mleczkę na artystę (jeśli nie wybitnego, to niewątpliwie aspirującego do takiego miana)

7 S. Magala Komiks w kulturze narodowej, "Kultura” $1978 \mathrm{nr} 34$. 
i wyrażał uznanie dla artystycznego potencjału tkwiącego w komiksie jako reprezentancie kultury masowej. Pośrednio była to zachęta do uważniejszego przyglądania się produktom popkultury i do zmiany sposobu ich postrzegania i oceniania.

Zaskakujące jest to, że komiksy satyryczne i seryjne opowieści przygodowe (zabarwione dydaktyzmem i propagandą) funkcjonowały w dwóch różnych obiegach. Niby były czytane przez tych samych odbiorców (czasem też różnych), ale nie były traktowane tak samo. Dobitnie pokazuje to książka Bartosza Kurca TRZASK PRASK, w której znalazły się wywiady z twórcami polskich komiksów, w tym z Rosińskim, Polchem, Christą, Chmielewskim, przedstawicielami młodszego pokolenia autorów, a także z Bohdanem Butenko - mistrzem komiksu i ilustracji dla dzieci. Na próżno w niej jednak szukać rozmów z Mleczką, Dudzińskim, Czeczotem czy ich kolegami ze „Szpilek”.

W 1976 roku zaczął ukazywać się magazyn „Relax”, pomyślany jako nowoczesne pismo komiksowe, zbliżone charakterem do periodyków zachodnich (wzorem był w tym wypadku francuski magazyn „Pilote”). Jego redakcję tworzyli: dziennikarz Henryk Kurta, emerytowany wojskowy i dziennikarz „Żołnierza Polskiego" Adam Kołodziejczyk, Grzegorz Rosiński, pełniący funkcję kierownika artystycznego i drugi rysownik - Ryszard Morawski. W pierwszym numerze swoje prace komiksowe zamieścili Janusz Christa, Bogusław Polch, Szymon Kobyliński, oczywiście - Rosiński i dwaj debiutanci: Bogusław Pawłowski i Tadeusz Baranowski. Jerzy Wróblewski do grona współpracowników magazynu dołączył w numerze czwartym.

Oficjalnie mówiło się o tym, że „Relax” miał być pismem dla wszystkich. Za hasłem tym kryło się adresowanie różnych części magazynu do różnych grup odbiorców. Dlatego właśnie znalazły się tam także komiksy o lekkim (naprawdę lekkim) zabarwieniu erotycznym oraz strona z przepisami kulinarnymi. Potem okazało się, że po pismo sięgają głównie dzieci i zrezygnowano zarówno z obyczajowych śmiałości, jak i z przepisów. Choć oficjalnie się o tym nie mówiło, z przejrzenia pierwszych numerów magazynu można wywnioskować, że miało to być dostępne dla różnych grup twórców komiksowych, reprezentujących odmienne style i koncepcje tworzenia opowieści rysunkowych. Kobyliński narysował swój komiks w sposób zbliżony do prac rysowników inspirujących się pop artem, takich jak Guy Peellaert, autor komiksów Les aventures de Jodelle (1966) i Pravda le Survireuse (1967). U Rosińskiego

8 Por. B. Kurc TRZASK PRASK. Wywiady z Mistrzami polskiego (i nie tylko) komiksu, Bajka, Koluszki 2004 . 
i Polcha widać dążenie do rysowania takich komiksów, jakie powstawały wówczas we francuskim głównym nurcie, tworzonych przez takich twórców jak Jean-Claude Mezieres i Paul Gillon. Christa i Baranowski wykorzystywali w swoich pracach konwencje i wzory komiksu humorystycznego. Pawłowski reprezentował komiks undergroundowy, czy też z undergroundu się wywodzący. Pojawienie się rysunków Andrzeja Mleczki w drugim i trzecim numerze "Relaxu" miało najpewniej służyć jako wzmocnienie reprezentacji tej odmiany opowieści rysunkowych. W ostateczności jednak Pawłowski dla „Relaksu" narysował później jeszcze tylko jedną opowiastkę i zniknął. Rolę reprezentanta komiksu antyestetycznego (czy też operującego groteskowym przerysowaniem) przejął wówczas Witold Parzydło, któremu jednak często dawano do opracowania scenariusze zupełnie nie pasujące do stylu jego rysunków, takie jak Ziemniaki i król, Barykada na Woli czy Srebrny medalion.

W „Relaksie” nie pojawiały się przedruki komiksów zachodnich, ponieważ nie było dewiz na ich zakup. Rosiński wpadł jednak na pomysł, że zaprosi do pisma twórców z Europy Wschodniej. W drugim numerze pisma pojawiły się komiksy z Czech i Węgier. Autorami komiksu czeskiego byli bracia Jan i Karel Saudkowie, a węgierski miał scenariusz Timora C. Horwatha i rysunki Imre Seboka. Czeska opowieść o zamachu na Reinharda Heydricha była szalenie dynamiczna i nowoczesna. Prace Węgrów przypominały amerykańskie komiksy przygodowe z lat 30. To te drugie jednak zagościły w magazynie na dłużej. Niedobór prac zagranicznych skutecznie niwelowały komiksy Rosińskiego. Rysownik podjął wówczas współpracę z belgijskim wydawnictwem Le Lombard i na podstawie scenariusza Jeana Van Hamme'a rysował komiks Thorgal, ukazujący się w odcinkach w magazynie „Tintin”. W „Relaksie” był on publikowany od dziewiętnastego numeru, natychmiast stając się największą atrakcją magazynu.

W tekście „Relax” (1976-1981) krótka historia magazynu komiksowego Adam Rusek napisał, że w wypowiedziach dawnych współpracowników pisma jest tyle rozbieżności, że czasem trudno ustalić, jak było naprawdę? . Wiadomo, że Henryk Kurta, choć pozostawał jego redaktorem naczelnym, przestał dość szybko interesować się magazynem, a jego obowiązki przejął Adam Kołodziejczyk. Rosińskiego z kolei coraz bardziej pochłaniała praca dla zachodniego wydawcy. Uszczuplona redakcja nie do końca realizowała początkowe założenia, częściowo dlatego, że trzeba było zmienić profil pisma (rezygnując

9 Zob. A. Rusek „Relax” (1976-1981): krótka historia magazynu komiksowego, w: I. Kiec, M. Traczyk Komiks i jego konteksty, Instytut Kultury Popularnej, Poznań 2014, s. 91 i n. 
z przeznaczonej dla dorosłych szczypty erotyzmu), częściowo zaś z powodu odmiennych upodobań. Na początku XXI wieku, zapytany o przyczyny poniechania współpracy z „Relaksem”, Tadeusz Baranowski stwierdził, że po odejściu Kurty redakcja straciła ochotę na dalszą współpracę z nim. Kołodziejczyk - zapytany przez Ruska - wyjaśnił, że współpracy z Saudkiem nie kontynuowano, bo nie było dla niego dobrych scenariuszy. Tak, jakby nie można było wykorzystać gotowych prac Czecha, podobnie jak robiono to z pracami Węgrów.

Adam Rusek wspomina o tym, że w „Relaksie” oprócz twórców zapraszanych do współpracy przez redakcję publikowały też osoby narzucone przez decydentów, sprawujących kontrolę nad pismem. Do tych drugich należeli - między innymi - twórcy komiksu Bionik Jaga. Do pierwszych zaliczał się Marek Szyszko, który został wypatrzony przez Grzegorza Rosińskiego na wystawie prac dyplomowych warszawskiej ASP (dyplom zrobił w pracowni Janusza Stannego). Współpracował z „Relaksem” do końca, zajmując na jego łamach coraz więcej miejsca.

Początkowo „Relax" ukazywał się regularnie i z dużą częstotliwością, lecz w 1979 roku wydano tylko cztery numery magazynu, w roku następnym trzy, a w 1981 zaledwie dwa, obwieszczając jednocześnie zamknięcie pisma. Trudno się temu dziwić: w kraju pogłębiał się kryzys, zmieniały się nastroje społeczne, zmieniła się rządząca ekipa, a wraz z nią kierunki rozwoju polityki kulturalnej. Adam Rusek napisał: „Dziś dla wielbicieli komiksu w Polsce «Relax» jest legendą i symbolem krajowych historii obrazkowych z PRL [...]"10. I tak rzeczywiście jest, chociaż jednocześnie za symbole „Złotego Wieku” polskiego komiksu uważa się prace, które ukazały się poza magazynem. Komiksem numer jeden wśród nich pozostaje Tytus, Romeki A'Tomek, których twórca ani jednej planszy do „Relaksu” nie zrobił. Zaraz potem należy wymienić komiksy Tadeusza Baranowskiego, powstałe po tym, jak autor ten zaprzestał współpracy z magazynem i zaczął drukować w „Świecie Młodych” i w „Razem” i wydawać samodzielne albumy. Na trzecim miejscu umieściłbym serial Kajko $i$ Kokosz, który przez moment w „Relaksie” gościł, ale nie był tam chciany z powodu podobieństwa do „Asteriksa”. W związku z tym Janusz Christa zrobił dla „Relaksu” mnóstwo innych rzeczy, uważanych dziś za margines jego twórczości, a Kajka i Kokosza drukował w „Świecie Młodych”, z którym związana była też Szarlota Pawel, od 1974 roku drukująca tam serial Jonka, Jonek i Kleks. Doskonale pamiętany z „Relaksu” Bogusław Polch opublikował w nim tylko 
jeden - ośmiostronicowy - komiks Spotkanie, a potem dostał kontrakt na rysowanie serialu science fiction Die Götter aus dem All (ze scenariuszem Arnolda Mostowicza i Alfreda Górnego) dla niemieckiego wydawnictwa Econ (publikowany w latach 1978-1983). W Polsce był on wydawany od 1982 roku pod tytułem Wedtug Ericha von Dänikena.

Niewątpliwie „Relax” pokazał inne oblicze Rosińskiego i Wróblewskiego jako twórców komiksowych i pokazał czytelnikom, że komiks może wyglądać inaczej. Wylansował też Marka Szyszkę, który poza magazynem kariery jako twórca komiksowy raczej by nie zrobił i który ostatecznie po 1989 roku z robienia komiksów zrezygnował. W latach 80 . Szyszko znalazł zatrudnienie jako kontynuator serii, które wcześniej rysował Grzegorz Rosiński: Pilot śmigłowca i Początki państwa polskiego. Narysował też bardzo udaną adaptację Doktora Jekylla i mr Hyde'a (1983) ze scenariuszem Stefana Weinfelda (głównego scenarzysty „Relaksu”) oraz Sąd Parysa (1986) ze scenariuszem Jacka Bocheńskiego. Brał również udział w tworzeniu serii Polscy podróżnicy. W rozmowie z Kurcem Szyszko bardzo mocno narzekał na realia rynku komiksowego w owym czasie, zdradzając, że wydawnictwo Sport i Turystyka dążyło do zmniejszenia kosztów, żądając robienia plansz w skali 1:1, co powodowało obniżenie jakości rysunków i rysowania ich od razu w kolorze, a także pogarszało jakość wydruków.

„W przeciwieństwie do «Relaxu» było to wydawnictwo pozbawione ambicji stworzenia polskiego komiksu. Komiks był tylko popularną i prostą w produkcji formą propagowania czy to nauki, historii, czy też innych treści edukacyjnych. Autorzy tekstów nie byli scenarzystami komiksowymi i o komiksie mieli zupełnie powierzchowne pojęcie. Nie byliby w stanie stworzyć postaci bohaterów komiksu. Pan Weinfeld był bardzo miłym starszym panem; chyba nawet nie literatem - raczej popularyzatorem nauki i być może pracował w NOT-cie"11.

W latach 8o.skończono z publikowaniem propagandowych seriali i zamknięto „Relax”, a wydawnictwa, które nadal wydawały komiksy, obniżały jakość publikacji i bazowały na sprawdzonych wzorach i autorach, nie zauważając, że świat idzie naprzód. Ale wtedy - dokładnie zaś w 1982 roku - ukazała się „Fantastyka”, a na jej łamach komiks Funky Koval. Autorami scenariusza byli członkowie ówczesnej redakcji Maciej Parowski i Jacek Rodek, za rysunki odpowiadał Bogusław Polch. Bohaterem komiksu był kosmiczny detektyw, a sama opowieść początkowo składała się z zamkniętych epizodów, w których

11 M. Szyszko Szkoła rysunku realistycznego, w: B. Kurc TRZASK PRASK..., s. 160. 
pojawiały się te same postacie. Wkrótce jednak scenarzyści zaczęli splatać poszczególne wątki opowieści, tworząc intrygę na kosmiczną skalę. Komiks odróżniał się na plus od reszty krajowej produkcji zarówno oryginalnością fabuły jak i jakością wykonania. W dodatku dzięki czytelnym aluzjom do tego, co się wówczas w Polsce działo, stanowił komentarz do współczesności i lokował się na pozycjach opozycyjnych wobec wszystkich komiksów nasyconych propagandą.

W 1987 roku zaczęto wydawać komiksowy dodatek do miesięcznika, zatytułowany „Komiks - Fantastyka”, który numer był de facto albumem komiksowym uzupełnionym symboliczną porcją publicystyki. W pierwszych numerach opublikowano zebrane w całość opowieści o Funkym Kovalu i cztery części serialu Yans, rysowanego przez Grzegorza Rosińskiego do scenariusza André-Paula Duchâteau, oryginalnie wydawane w Belgii. W siódmym, wydanym już w 1989 roku, opublikowano kilka tekstów publicystycznych i krótkich komiksów, w tym także wykonanych przez polskich twórców. W rok później ponownie opublikowany został numer publicystyczny, z podobną zawartością. W nich obu znalazły się - między innymi - prace młodych polskich rysowników, pokazujące, że dorosło pokolenie wychowanych na „Relaksie”. Wśród rysowników, których prace wówczas pokazano, znaleźli się Jerzy Ozga, Sławomir Jezierski, Marek Wdziękoński, Sławomir Wróblewski i - przede wszystkim - Krzysztof Gawronkiewicz.

Najbardziej elektryzująca była zapowiedź komiksu Burza ze scenariuszem Macieja Parowskiego i rysunkami Gawronkiewicza. Miała to być alternatywna historia II wojny światowej, mająca za punkt wyjścia pytanie, co by było, gdyby we wrześniu 1939 roku padało, a właściwie - lało jak z cebra. Odpowiedź brzmiała, że w takim wypadku armia niemiecka ugrzęzłaby na rozmytych polskich drogach i została z łatwością rozbita przez poruszających się konno ułanów. Wojna skończyłaby się w dwa tygodnie, a wzięty do niewoli Adolf Hitler zostałby wywieziony na Wyspę Świętej Heleny w asyście trzech polskich niszczycieli: „Burzy”, ,Gromu” i „Błyskawicy”. Scena, w której Hitler w ulewnym deszczu wsiada na statek, była pierwszym opublikowanym fragmentem komiksu. Wzbudziła ono żywe zainteresowanie czytelników powstającym dziełem, ale wydaje się, że rozbudziła także oczekiwania scenarzysty, który zaczął swoją opowieść wzbogacać. Dodał do niej postacie Gombrowicza i Witkacego, którzy przechadzając się po Warszawie, komentują to, co się dzieje i dopowiadają to, co autor chciał wyrazić. Dodał też pomysł z kręceniem filmu (komedii), opowiadającego o tym, co by było, gdyby Niemcy tej wojny nie przegrali tak szybko. Umożliwiło to wprowadzenie na 
karty komiksu postaci powstańców warszawskich, japońskich myśliwców, Marleny Dietrich i pijanego Broniewskiego.

Fragmenty tej nowej, rozbudowanej i przebudowanej Burzy ukazały się na łamach „Komiksu” (w 1993 roku) i „Komiks Forum (w 1996), całość nigdy jednak nie ujrzała światła dziennego.

„Komiks był zamówiony przez «Fantastykę»” - wspominał Gawronkiewicz. - „Robiłem go tak, by odcinki miały cztery strony i się puentowały, by czytelnik czekał miesiąc na ciąg dalszy. Bez żadnej umowy, bo byłem debiutantem dojechałem do 20 strony. Niemalże do połowy albumu. Pytałem się w redakcji, kiedy wydrukują. I nagle powiedzieli, że nie wydrukują. Było zamówione i potem okazało się, że nie było. Nie chcę się żalić, bo to stare dzieje, ale gdy Burzy nie chciano, wydrukowano Naród wybrany Parowskiego i Jarosława Musiała"12.

W 2003 roku czternastostronicowa wersja komiksu znalazła się w antologii Wrzesień. Wojna narysowana, a w 2015 w albumie Krzesło w piekle, wydanym z okazji retrospektywnej wystawy prac Gawronkiewicza, zorganizowanej w BWA w Zielonej Górze, pojawiła się wersja licząca stron dwadzieścia jeden. Wydaje się, że po rozstaniu z „Fantastyką” Gawronkiewicz już do Burzy nie wracał. W 1993 roku zajął się bowiem innym projektem, w 1994 dołączył do niego kolejny. Pierwszy z nich nosił tytuł Achtung Zelig! a drugi Mikropolis. Tymczasem Maciej Parowski przerobił scenariusz na powieść, która została opublikowana w 2010 i wznowiona w 2013 roku. Na okładce drugiego wydania znalazło się połączenie rysunku Gawronkiewicza z fotografią warszawskiej ulicy z okresu, o którym mówi powieść - bardzo udany symbol przenikania się dwóch rzeczywistości.

W 1990 roku miesięcznik „Fantastyka” przekształcił się w „Nową Fantastykę", a towarzyszący mu kwartalnik poświęcony komiksom w pismo „Komiks". Wiązało się to z przejęciem pisma przez nowego, prywatnego wydawcę, od którego w 1991 roku przeją je kolejny prywatny wydawca. W Polsce zaczynał się wolny rynek, co miało związek z pojawieniem się konkurencji, ale też z inflacją, ubożeniem społeczeństwa, wzrostem cen i spadkiem czytelnictwa książek. W tym wszystkim najwolniej zmieniała się świadomość wydawców, których oczekiwania co do wysokości sprzedanych nakładów znacznie przewyższały realne możliwości. „Komiks” został zamknięty w 1995 roku, ale wówczas - podobnie jak i rok wcześniej - opublikowano tylko dwa numery pisma (w 1993 było ich dziesięć). Jedynymi Polakami, którzy swoje

K. Gawronkiewicz Miałem klapki na oczach, w: B. Kurc TRZASK PRASK..., s. 51. 
prace w piśmie publikowali w całości, a nie tylko w postaci próbek, pozostali do końca Parowski i Polch (Rodek odszedł i założył własne wydawnictwo). Na podstawie niezwykle popularnego cyklu opowiadań Andrzeja Sapkowskiego stworzyli oni sześcioczęściowy serial Wiedźmin. To on był ostatnią rzeczą, jaką opublikowano w magazynie „Komiks”.

Okres wkraczania polskiego komiksu na wolny rynek obrósł wieloma legendami i wywołuje nader skrajne i przeciwstawne oceny, czasem nawet wygłaszane przez tych samych ludzi w różnych okresach. Na przykład Szymon Holcman (publicysta i wydawca) w 2006 roku twierdził, że „W «nowej» Polsce komiks wpadł w prawdziwą czarną dziurę. Odwrócili się od niego wydawcy i czytelnicy, nakłady z poprzedniej epoki przestały mieć rację bytu. I w ten sposób komiks zszedł do podziemia. Stworzyli je oddolnie młodzi rysownicy i wielbiciele, «dzieci», które z komiksu nie wyrosły, bo nie widziały w tej fascynacji niczego dziecinnego"13.

W grudniu 2010 w „Kulturze Liberalnej”, w artykule zatytułowanym Skąd, gdzie, dokąd? - komiks polski po dwóch dekadach wolnego rynku można było natomiast przeczytać, że

Pierwsza [dekada - J.Sz.], obejmująca prawie całe lata 9o., była wyjątkowo intensywnym życiem polskiego komiksu w trzecim, ewentualnie drugim obiegu - mówi Szymon Holcman. - Podczas gdy do masowego czytelnika trafiały zeszyty publikowane przez TM-Semic, rodzimi komiksiarze tworzyli głównie do zinów (np. punkowych, jak Dariusz „Pała” Palinowski czy Krzysztof „Prosiak” Owedyk) i nielicznych magazynów (nieodżałowane „AQQ”, później też „Arena Komiks”). Spotykali się podczas łódzkiego konwentu komiksowego, który mobilizował wszystkich konkursem na krótką formę komiksową. To zgłoszone na niego prace stanowią dziś kanon współczesnego polskiego komiksu i są świetnymi próbkami talentu takich gwiazd jak Przemek Truściński, Krzysztof Gawronkiewicz, Jacek Frąś, Krzysztof Ostrowski i inni. Zaryzykowałbym tezę, że był to najbardziej kreatywny i różnorodny okres w historii polskiego komiksu. ${ }^{14}$

13 Sz. Holcman, wypowiedź przytaczana w tekście: J. Woynarowski Story art. W poszukiwaniu awangardy polskiego komiksu, w: P. Marecki Kultura niezależna w Polsce 1989-2009, Korporacja Ha!Art, Kraków 2010, s. 179.

Wypowiedź przytaczana w tekście: B. Biedrzycki Skąd, gdzie, dokąd? Komiks polski po dwóch dekadach wolnego rynku, "Kultura Liberalna” $2010 \mathrm{nr}$ 102, http://kulturaliberalna.pl/2010/12/21/ biedrzycki-skad-gdzie-dokad-\%E2\%80\%93-komiks-polski-po-dwoch-dekadach-wolnegorynku/ (29.07.2017). 
Druga z tych wypowiedzi wywołała gniewne żachnięcie się rysownika Macieja Pałki, który w felietonie To generał Jaruzelski zabił polski komiks! napisał:

Wchodzimy właśnie w nową dekadę. Zgodnie z niepisaną zasadą, poprzednia dekada przestaje być obciachowa. Znajduje to również odbicie w postrzeganiu polskiego komiksu. Nagle lata'9o z epoki wielkiej smuty i mentalnej koniobijki mistrzów pierwszej planszy stają się „najbardziej kreatywnym i różnorodnym okresem w historii polskiego komiksu". Dekada '80 zostaje zdegradowana jako czas upadku, a znów lata'70 awansują do miana wspominanych z nostalgią legendarnych czasów. Na szczęście już w 2021 sinusoida znowu dygnie i moja wizja świata ponownie stanie się aktualna. ${ }^{15}$

Kluczem do zrozumienia, co wydarzyło się w latach 9o. na scenie komiksowej, wydaje się być określenie „trzeci obieg” czy też „fanzin”. O zjawisku tym Dominik Szcześniak pisał na łamach „Zeszytów Komiksowych":

Impuls do rozwoju polskiego ruchu fanzinowego pojawił się po 1989 roku, po zniesieniu cenzury, w okresie erupcji gazetek literackich wydawanych własnym sumptem. Fanziny komiksowe pojawiające się od początku lat dziewięćdziesiątych to twory typowo undergroundowe, związane z konkretnymi subkulturami, na czoło których zdecydowanie wybiła się subkultura punkowa. Mocno z nią związane były dwie postacie, uważane dziś za trzon komiksu podziemnego w Polsce: Krzysztof Owedyk oraz Dariusz Palinowski. Pierwszy jest twórcą zina Prosiacek, natomiast drugi - Zakazanego owocu. ${ }^{16}$

"Czarna dziura" na początku lat 9o. nie była ani tak bezdenna, ani tak czarna, jak niektórzy sugerują. Upadające państwowe oficyny, w tym moloch wydawniczy, jakim był KAW, mający własne oddziały w niemal każdym mieście wojewódzkim, walczyły o przetrwanie. Konkurowały z nimi nowo powstające oficyny prywatne szukające sposobu, by odnieść szybki sukces. I jedne, i drugie uważały, że zapewnią go im komiksy. Przy czym niemal nikt nie myślał wówczas o wydawaniu komiksów zachodnich (wspomniane przez Holcmana

15 M. Pałka To generał Jaruzelski zabił polski komiks!, "Ziniol” 9.01.2011 http://ziniol.blogspot. com/2011/01/to-genera-jaruzelski-zabi-polski-komiks.html (30.07.2017). 
TM-Semic było spółką polsko-szwedzką, która prawo do wydawania komiksów amerykańskich kupowała na kilka krajów) i niemal wszystkim wydawało się, że komiksy krajowe zaspokoją oczekiwania odbiorców. Efekt był taki, że komiksy było wydawać łatwo, jak nigdy dotąd. I niektórzy z tego skorzystali. W 1990 powstały dwa nowe magazyny komiksowe: jeden w Gdańsku, drugi w Bydgoszczy. Nazywały się „Fan” i „Awantura”, zakończyły swoje żywoty po opublikowaniu czterech numerów. Ale rysujący do jednego z nich twórca z Bydgoszczy Jacek Michalski opublikował dwa komiksy już w 1989 roku. Nosiły tytuły Zagadka metropolii (Wydawnictwo Pomorze) i Roy (AKAR). Związany z drugim magazynem Sławomir Jezierski z Gdyni pierwszy komiks, zatytułowany Olbrzymy na wyspie (Spółka Wydawniczo-Księgarska) wydał w 1990, drugi - Alicja w krainie czarów (Oficyna Wydawnicza Graf) w 1992. Weteran, jakim był wówczas Jerzy Wróblewski (rysownik zmarł nieoczekiwanie w 1991 roku, miał wówczas 50 lat), na przestrzeni dwóch lat opublikował dwanaście komiksów. Trzy z nich były ze scenariuszami Mirosława Stecewicza.

Stecewicz, poeta z Sopotu, autor książek dla dzieci, na przełomie lat 8o. i 9o. przygotował dla wydawców propozycje opublikowania komiksów na podstawie jego przeznaczonej dla najmłodszych opowieści o wyspie Umpli-Tumpli, nawiązał kontakt z rysownikami, którzy przygotowali mu plansze próbne ruszył w objazd po wydawnictwach. W szczecińskim Globie (który powstał w wyniku sprywatyzowania oddziału KAW) zaproponowano mu, żeby Jerzy Wróblewski zastąpił Sławomira Jezierskiego. W efekcie duet ten zrobił i opublikował tych komiksów trzy: jeden wydał Glob, drugi opublikowało Młodzieżowe Centrum Kultury w Gdyni, a trzeci ukazał się w wydawnictwie o mikroskopijnym dorobku i pięknej nazwie: Centrum Sztuki Gdynia. Na szczęście w innym wydawnictwie przyjęto kolejny scenariusz i zaaprobowano rysunki Jezierskiego. W jeszcze innym (noszącym nazwę Intercor) wydano kolejne trzy komiksy z rysunkami Andrzeja Szadkowskiego i jeszcze jeden, za którego oprawę graficzną odpowiadała osoba podpisująca się G. Figas. Było jeszcze wydawnictwo Starkey, które wydało dwie opowieści z wyspy Umpli-Tumpli narysowane przez Krzysztofa Kiwerskiego i jego żonę Jolantę. Dziesięć komiksów wydanych w dwa lata i to przez człowieka, który wcześniej tworzeniem opowieści rysunkowych się nie parał. Wydawać by się mogło, że to symptom jakiegoś gigantycznego boomu komiksowego a nie „czarnej dziury”.

$\mathrm{Na}$ początku lat 9o. naprawdę rozpadał się dawny system wydawniczy i naprawdę radykalnie malała liczba osób gotowych kupować komiksy, a zwłaszcza komiksy polskie. W ówczesnych warunkach każdy komiks 
skazany był na klęskę, niezależnie od jakości, ale dużo łatwiej było o publikację niż kilka lat wcześniej. Skąd zatem wyobrażenie, że „wszyscy się odwrócili”. Ano stąd, że twórcy komiksów po raz pierwszy rozejrzeli się dokoła i zobaczyli, ilu ich naprawdę jest. A zrobili to, bo zapragnęli naśladować działania podejmowane przez miłośników fantastyki naukowej, którzy organizowali własne konwenty (i niejednokrotnie zapraszali na nie twórców komiksowych), wydawali - poza oficjalnym obiegiem - własne fanziny, w których prezentowali twórczość własną i (częściej) cudzą.

Pierwszy Konwent miłośników komiksów został zorganizowany w 1991 roku w Kielcach, a drugi odbył się - jeszcze w tym samym roku - w Łodzi i tu przerodził się w imprezę cykliczną, która odbywała się rokrocznie i nadal odbywa, obecnie jako Międzynarodowy Festiwal Komiksu i Gier. Impreza, organizowana przez wiele lat, przyciągała miłośników komiksu giełdą, na której można było różne rzeczy stare i niedostępne kupić, twórców - konkursem na krótką formę komiksową, w którym nagrody były symboliczne, wszystkich zaś możliwością poznania siebie nawzajem. Przy okazji nawiązywania kontaktów twórcy podejmowali decyzje o opublikowaniu czegoś wspólnie. Cenzury już nie było, dostęp do ksero był łatwy, pragnienie, by coś zrobić - ogromne. Byli też ludzie, którzy chcieli środowisko komiksowe integrować. Witold Tkaczyk z Poznania założył fanzin „AQQ”, pełniący rolę środowiskowego informatora. Ukazywał się od 1993 do 2004 roku i w pewnym momencie przekształcił w profesjonalną publikację. Sam Traczyk zaś założył wydawnictwo o nazwie Zin Zin Press, które zaczęło ambitnie od publikacji komiksu Achtung Zelig! Gawronkiewicza i Rosenberga, a potem skupiło się na tworzeniu na zamówienie i we współpracy z Narodowym Centrum Kultury i innymi instytucjami państwowymi komiksów historyczno-patriotycznych, takich jak Solidarność - 25 lat (2005), Ksiądz Jerzy Popietuszko: cena wolności (2005) czy 1981: Kopalnia Wujek (2006). Ale to już zupełnie inna historia.

Problem polegał na tym, że dla wielu spośród owych rysowników uczestniczenie $\mathrm{w}$ wystawach, branie udziału w konkursach i publikowanie w fanzinach było okazją, by pokazać swoje umiejętności jakiemuś „profesjonalnemu wydawcy" - nie wiadomo, jakiemu, jakiemukolwiek. Wykonywali oni swoje prace starannie, ale rysowali niewiele, tylko tyle, ile było trzeba, żeby pokazać, że potrafią. To ich właśnie Maciej Pałka nazywa „mistrzami pierwszej planszy" i obraża w swojej wypowiedzi, ani przez moment nie zastanawiając się nad tym, że w latach 8o. nie mógłby na temat tych prac się wypowiadać, bo by ich na oczy nie zobaczył, gdyż wtedy nie było ani konwentów, ani 
fanzinów, a „pierwsze plansze" leżały w szufladach redaktorów wydawnictw i czasopism i czekały na zmiłowanie.

Wraz z nadejściem „czasów xero”, które można również nazwać „złotym wiekiem konwentów", bo w pewnym momencie zloty, zjazdy i spotkania miłośników komiksów zaczęły być organizowane od Gdańska po Kraków, prace nieopublikowane (i często niegotowe do publikacji) zaczęły być pokazywane i były oglądane. Zaczęły też być komentowane, oceniane i porównywane. Środowisko komiksowe działało jak żywa ilustracja tezy Waltera Benjamina na temat dzieła sztuki w dobie reprodukcji technicznej: radość płynąca z patrzenia i przeżywania splotła się w nim z postawą fachowego krytyka. Boleśnie odczuł to w swoim czasie Maciej Parowski jako autor scenariusza do komiksowego Wiedźmina i stały bywalec konwentów zarówno komiksowych, jak i fantastycznych.

Popularne utwory Sapkowskiego pobudzały wyobraźnię wielu twórców komiksów, kiedy zatem w „Komiksie” pojawiła się pierwsza zapowiedź narysowanej przez Polcha adaptacji, w fanzinach zaczęły pojawiać się kontrpropozycje, przykłady tego, jak Wiedźmin powinien wyglądać "naprawdę” i narzekania. Nie ma jednak racji Parowski twierdząc, że „najzacieklej krytykowali Wiedźmina ci, którzy nie mogli go rysować, bo nie dostali zamówienia"17. Krytykowali go fani, którym po raz pierwszy dano możliwość porównania różnych wersji tego, co mogłoby być i jednocześnie możliwość wypowiedzenia się na ten temat. Dziś, kiedy tego rodzaju prezentacje próbek twórczości i komentarze na ich temat przeniosły się do internetu, byłoby jeszcze gorzej.

W fanzinach niektórzy prezentowali kilka swoich plansz, inni zaś kilkadziesiąt, w ostatecznym rozrachunku jednak w tym trzecim obiegu prezentowali się wszyscy i to właśnie w kontakcie z owymi amatorskimi, kserowanymi, nie zawsze dobrze reprodukowanymi pracami można było doświadczyć poczucia bogactwa polskiego komiksu, którego nie mogło zapewnić żadne profesjonalne wydawnictwo, bo praca tychże opiera się na skrupulatnej selekcji i odrzucaniu tego, co nie pasuje ${ }^{18}$. Dlatego właśnie Szymon Holcman ma rację, gdy stwierdza, że lata 9o. były najbardziej kreatywnym i różnorodnym okresem w historii polskiego komiksu. Lata 9o. były bowiem okresem potencjalności i trwania w gotowości do tego, by coś zrobić. Wraz z początkiem XXI wieku zaczął się natomiast okres selekcji i odrzucania.

M. Parowski Jestem sługą literatury, w: B. Kurc TRZASK PRASK..., s. 103.

18

Pytanie, czy nie pasuje „komuś”, czy „do czegoś” jest dość istotne, ale nie da się na nie odpowiedzieć bez plotkowania. 
Wśród miłośników komiksów (w tym także ich twórców) zawsze istniał podział na tych, którzy w historiach obrazkowych cenili przygodę, humor i ładne obrazki i tych, którzy spośród komiksów chętniej wybierali te, w których pojawiają się eksperymenty formalne, treści kontestacyjne, groteskowe przerysowania i satyra ostrzem skierowana w stronę rzeczywistości lub w kierunku schematów i formuł, na których oparte zostały podwaliny narysowanych światów. Podział ten był widoczny już w „Relaksie”, z którego twórców komiksów z tej drugiej grupy skutecznie eliminowano, czemu też trudno się dziwić, bo popyt na prace z grupy pierwszej zawsze i wszędzie był większy.

W „czasach xero" relacja między tymi grupami uległa charakterystycznej zmianie, bowiem rysownicy komiksów z ładnymi obrazkami częściej znajdowali zatrudnienie w czasopismach: Jezierski rysował dla „Playboya” komiks Misjonarze (scenariusz: Konrad Szołajski i Kamil Śmiałkowski) ukazujący się w latach 1994-1995; Śledziński od 1995 współpracował ze „Światem Gier Komputerowych”; Robert Adler od 1997 z „Resetem”; Rafał Skarżycki i Tomasz Lew Leśniak ze swoim Jeżem Jerzym w 1996 roku wylądowali równolegle w „Świerszczyku” i „Ślizgu”. Kto nie publikował w czasopismach, pracował na bujnie rozwijającym się rynku reklamy - do dziś większość rysowników tam właśnie znajduje zajęcie. Twórcy komiksowych eksperymentów i komiksów kontestujących rzeczywistość, świadomi tego, że swoimi pracami komercyjnego rynku nie podbiją, od razu całą energię skierowali na produkcję fanzinów, traktując je jako ostateczną formę prezentacji swojej twórczości. Dlatego ich prac pojawiało się więcej, były lepiej znane i szerzej komentowane. Wywoływało to ataki ze strony fanów (czasem też publikujących w prasie krytyków) i oskarżenia o to, że owe komiksy „artystowskie” blokują rynek i odbierają możliwości publikacji „naprawdę dobrych" komiksów, jakbyśmy nadal żyli w czasach państwowego monopolu wydawniczego i reglamentacji papieru. Co zabawne, z powtarzaniem tego typu argumentów można spotkać się także dzisiaj.

Koniec pewnej epoki wiązał się z tym, że wydawnictwo Egmont zaczęło wydawać magazyn „Świat Komiksu” (w 1998 roku) i uruchomiło serię komiksową „Klub Świata Komiksu”, w ramach której zaczęły się ukazywać komiksowe albumy, wśród nich - prace Polaków. Zaczęło się od antologii Komiks: najlepsi młodzi rysownicy (2000), w której znalazły się przede wszystkim komiksy nagrodzone na łódzkich konkursach. Potem ruszyła autorska seria Piotra Kowalskiego Gail (2001) - fantastyczny komiks przygodowy, sprawnie narysowany, spełniający wszelkie wymogi dzieła komercyjnego, wyszedł 
album Śledzińskiego Fido i Mel: Na kozetce (2001), wybór jego prac ze „Świata Gier Komputerowych" oraz pierwszy tom serii Status 7 (2001) Adlera i Piątkowskiego - też znany z wcześniejszej publikacji w prasie i wreszcie ukazał się Jeż Jerzy nie dla dzieci (2002) - przedruk prac znanych ze „Ślizgu”.

W czasie, gdy Egmont wydawał pierwszy polski komiks, na taki sam ruch zdecydował się również wrocławski Siedmioróg, który w 2001 roku opublikował Mikropolis: przewodnik turystyczny Gawronkiewicza i Dennisa Wojdy, ale w tym samym roku z oficyny tej odszedł Przemysław Wróbel, który założył własną oficynę o nazwie Mandragora i ściągnął do niej polskich twórców: oprócz Gawronkiewicza i Wojdy publikowali u niego Adler i Piątkowski, Rafał Gosieniecki, Jacek Michalski, Joanna Karpowicz.

Ów gwałtowny wzrost zainteresowania wydawców polską twórczością komiksową wynikał stąd, że jesienią 1999 trafił na rynek magazyn komiksowy „Produkt”, redagowany przez Michała Śledzińskiego, zawierający prace wyłącznie polskich twórców. Sprzedawał się znakomicie i budził zainteresowanie krytyki. Wydawała go oficyna o nazwie Niezależna Prasa, która - co okazało się z dużym opóźnieniem - była imprintem koncernu Axel Springer Polska. Po latach - z typową dla siebie publicystyczną przesadą - Wojciech Orliński napisał:

Michał „Śledziu” Śledziński to Jerzy Giedroyć polskiego komiksu. Założone przez niego pismo „Produkt” pomogło temu środowisku wydobyć się wreszcie z okresu wielkiej smuty lat 9o. Pismo już nie istnieje, ale do dzisiaj na polskim rynku komiksowym widać wpływ jego Redaktora można wręcz wejść do empiku i palcem pokazywać albumy, które nie leżałyby dziś na półce, gdyby w odpowiednim momencie odpowiedniego autora „Śledziu" nie zaprosił do współpracy z „Produktem”.9

Rzecz jasna, Śledziński żadnym „Giedroyciem komiksu” nie był, bo przede wszystkim - nie chciał.W „Produkcie” prezentował dość wąską grupę twórców, których lubił, bezpardonowo wyśmiewał i atakował (często mało wybrednie) tych, których nie lubił, a całkiem sporą grupę rysujących komiksy ignorował, kiedy przysyłali mu swoje prace do publikacji. Rzeczywiście jednak druk w „Produkcie” otwierał rysownikom drogę do innych wydawnictw.

19 W. Orliński Hit: „Na szybko spisane 1980-1990". Kit: "Ester i Klemens", "Wysokie Obcasy” [http:// www.wysokieobcasy.pl/wysokie-obcasy/1,96856,4572839.html?disableRedirects=true (30.07.2017). 
Skorzystali na tym Filip Myszkowski i Rafał Gosieniecki, których albumy opublikowała Mandragora, Karol „KRL” Kalinowski, który trafił do Egmontu i bracia Bartosz i Tomasz Minkiewiczowie, którzy swój prześmiewczy serial Wilq zaczęli wydawać własnym sumptem. Z czasem skorzystali też inni, którzy znaleźli wydawcę w Kulturze Gniewu - oficynie powstałej w 2000 roku, początkowo jednak skupionej na publikowaniu prac twórców związanych z komiksowym undergroundem - Krzysztofa Owedyka i Dariusza Palinowskiego.

W podjętych przez przedstawicieli Egmontu i Mandragory decyzjach, co opublikować, widać pewną ostrożność, polegającą na wybieraniu rzeczy już wcześniej sprawdzonych, mających jakąś grupę rozpoznawalnych odbiorców. Z pierwszych polskich komiksów opublikowanych przez Egmont bestsellerem okazał się JeżJerzy (który doczekał się nawet ekranizacji w 2011 roku). Druk Statusu 7 został przerwany po opublikowaniu drugiej części. Gail nie sprzedawał się za dobrze, ale czteroczęściowa seria została opublikowana w całości. Chociaż krytykowano ją dość bezpardonowo, wytykając twórcy najrozmaitsze braki, publikacja ta ułatwiła Kowalskiemu nawiązanie kontaktów z wydawcami zagranicznymi. Najpierw rysował komiksy dla Francuzów, obecnie współpracuje z wydawnictwami amerykańskimi. Współpracę ze Śledzińskim wydawnictwo zakończyło po jednym albumie. Wydawnictwo Mandragora splajtowało w 2008 roku, ale stało się to raczej z powodu złych decyzji związanych z publikowaniem komiksów amerykańskich, a nie z racji współpracy z polskimi twórcami.

I Śledziński w „Produkcie”, i redaktorzy zatrudnieni w Egmoncie, i Przemysław Wróbel w Mandragorze, działali, wybierając spośród tego, co oferowali im twórcy komiksowi i odrzucając całkiem sporą część ich oferty. Tym samym ustanowili rodzaj hierarchii opartej na tym, kto jest publikowany, kto zaś nie i zainicjowali demontaż owej wspólnoty, która zawiązała się w latach 90., w „epoce xero".

"Produkt" został zamknięty w 2004 roku, po opublikowaniu dwudziestu trzech numerów pisma. Moment ten można uznać za symboliczne zakończenie pewnej epoki, rozpoczętej rozpadem postpeerelowskiego systemu wydawniczego, co prowadziło do bardzo ciekawych i obfitujących w artystyczne objawienia czasów, które niektórzy nazywają okresem „wielkiej smuty" w dziejach polskiego komiksu i znalazło puentę w powstaniu nowych wydawnictw, wydawców i gwiazd komiksowego rynku. Upraszczając, można powiedzieć, że potem było już (i nadal jest) normalnie. Powstają nowe wydawnictwa, rodzą się nowe gwiazdy, świat się kręci. 
Na zakończenie warto wspomnieć o tym, że w roku zamknięcia "Produktu” Egmont opublikował dwa albumy polskich twórców. Jeden, zatytułowany Barbarzyńcy, autorstwa Rafała Urbańskiego, Norberta Rybarczyka i Janusza Ordona, był przygodową opowieścią fantasy, zapowiadaną szumnie jako początek długiej sagi, i był dopasowany do gustu tych, którzy cenili przygodę, humor i ładne obrazki. Drugi nosił tytuł Rewolucje, a jego autorem był gdańszczanin Mateusz Skutnik, jeden z bardziej aktywnych twórców „epoki xero" - jeden z tych, którzy wiedzieli, że nie mają czego szukać w komercyjnych wydawnictwach. Przyczyną, dla której zdecydował się złożyć propozycję w profesjonalnym wydawnictwie, było to, że Rewolucje były komiksem kolorowym, niemożliwym do powielenia na ksero we właściwej formie.

Rysownik opowiadał później, że kierujący Klubem Świata Komiksu Tomasz Kołodziejczak na jakimś spotkaniu z twórcami komiksów powiedział im, że opublikuje komiks tego twórcy, który przyniesie mu dwa albumy ten, do wydania i jego kontynuację, przygotowaną na wypadek, gdy sprzedaż będzie dobra. I Skutnik złapał go za słowo, przynosząc dwa albumy. Egmont opublikował Rewolucje, chociaż nie bardzo pasowały do całokształtu ich oferty wydawniczej i chociaż album ten był wówczas w całości dostępny w Internecie, umieszczony tam przez Skutnika, niewierzącego w możliwość jego publikacji. Komiks nie był specjalnie promowany, a środowiskowi publicyści wspominali o nim jedynie przy okazji pisania o Barbarzyńcach. A jednak pod koniec tego samego roku ukazał się kolejny album Rewolucji, a w 2005 trzeci. Komiks składał się z krótkich opowieści o wynalazcach i odkrywcach, żyjących gdzieś na przełomie XIX i XX stulecia w rzeczywistości nieco różniącej się od naszej, choć mającej z nią jakieś punkty styczne. W części czwartej, wydanej w 2006 roku, Skutnik połączył swoje opowieści w jedną intrygę i doprowadził do jej zamknięcia. Kołodziejczak ogłosił wówczas, że Egmont kończy publikację serii.

Kolejne albumy Rewolucji przyjmowane były z coraz większym uznaniem, aczkolwiek nie sprzedawały się najlepiej. Ich wydanie nie było dla Egmontu finansową klapa, ale sukcesem też nie były. Dlatego zapadła decyzja o zamknięciu serii. To, że Rewolucje w ogóle zostały wydane i przetrwały na rynku przez kilka lat można uznać za przejaw tego, że w „epoce xero” nastąpiło pewne pomieszanie porządków i to, co alternatywne okazało się na swój sposób komercyjne, a to, co komercyjne, straciło trochę na swojej atrakcyjności. Można też uważać, że jest to przejaw normalności właśnie. Na rynku, na którym można kupić komercyjne albumy francuskie, amerykańskie, włoskie, japońskie, wydawane u nas dlatego, że wcześniej stały się bestsellerami we 
własnym kraju i na całym świecie, na sukces można liczyć, jedynie robiąc coś oryginalnego i alternatywnego.

W 2009 roku Tomasz Bagiński na podstawie jednej z opowiastek z trzeciego tomu Rewolucji, zatytułowanej Kinematograf, zrealizował film animowany. Nie był to żaden sukces, ale w 2010 roku wydawnictwo Mroja Press opublikowało mały albumik noszący tytuł Rewolucje. Dwa dni. Zawierał on dwie krótkie historie narysowane przez Skutnika na potrzeby fanzinów, w których publikował. W 2011 wydawnictwo Timof i cisi wspólnicy opublikowało siódmy tom serii Rewolucje. I od tamtej pory - co roku - ukazuje się tom kolejny. W 2016 ukazało się zbiorowe wydanie pierwszych czterech tomów. Na rok 2017 Skutnik przygotował pierwszy tom zbiorowego wydania komiksów, które kiedyś publikował w fanizinie „Vormkfasa” (w nakładzie 50 egzemplarzy), a na rok 2018 planuje wydanie tomu drugiego. Zapowiedział jednak, że do Rewolucji powróci. W tym samym czasie inni wydawcy publikują komiksy innych polskich rysowników. Są to komiksy nowe i stare. Są między nimi także te, które powstały w okresie „wielkiej smuty”. Najlepiej jednak sprzedają się komiksy, które powstały w okresie PRL-u. Egmont jako tysięczny (jubileuszowy) album Klubu Świata Komiksu opublikował wybór najlepszych prac z magazynu „Relax”.

\section{Abstract}

\section{Jerzy Szyłak}

UNIVERSITY OF GDAŃSK

The Comic Book in Times That Are Not Necessarily Normal

Szyłak outlines the history of the comic book in Poland since 1956 and tries to account for the shifts that marked the development of this form of cultural production. He also presents a critical perspective on the evaluation of comic books in the past.

\section{Keywords}

Polish comic books, popular culture in the Polish People's Republic 